RADÁK JUDIT

\title{
VAJDA LAJOS „TÉRRAJZAI” AZ ANTIK EGYIPTOMI ÉS PERZSA TÉRFOGALOM ÉRTELMEZÉSEI ALAPJÁN
}

Kutatásom alapja Vajda Lajos írásos hagyatékának a feldolgozása. ${ }^{1}$ A fennmaradt írásos dokumentumok mennyisége nem számottevő. Három füzeten és néhány cédulán (füzetlapok, füzetlapdarabok, könyvtári kérólapok) kívül csak a feleségéhez írt és általa megőrzött levelei állnak rendelkezésünkre, illetve néhány, véletlenül megmaradt levél és levelezőlap. Az 1936 és 1941 között feleségével váltott és a hagyatékban megmaradt leveleknek teljes szövege 1996-ban jelent meg Jakovits Vera és Kozák Gyula, a Vajda-hagyaték gondozóinak szerkesztésében. ${ }^{2}$ A füzetek fekete-fehér kockás borítójára utalva Mándy Stefánia 1983-as monográfiájában használja a pepita jelzőt. ${ }^{3}$ A röviden ismertetett füzetekből Mándy négy oldalon keresztül közöl részleteket, amelyekben az olvasmányjegyzékek nem kapnak kellő hangsúlyt, pedig a füzetek főleg ezeket tartalmazzák. A Pepita füzetek alapján beazonosított közel 400 tételes olvasmánylistából és a hagyatékban megmaradt könyvekből tematikus bibliográfiát készítettem, amely megmutatta, hogy Vajda olvasottsága milyen érdeklődési területeket fedett le, illetve az is láthatóvá vált, hogy egy-egy téma a bibliográfia egészéhez képest arányaiban mennyire reprezentatív. ${ }^{4}$

Az írott forrásokból kiderül, hogy Vajdát különösen érdekelték a térelméletek, a különböző kultúrák térábrázolási megoldásai, így 1935 és 1937 között készült szentendrei városképeit és épületábrázolásait bemutatva ez lesz vizsgálódásom kiindulópontja. Vajda szentendrei házakat, utcákat ábrázoló műveit nagy mennyiségük ellenére csak érintőlegesen elemezték a szakirodalomban, rendszerint a "szentendrei programhoz" vagy a konstruktív szürrealista tematikához kapcsolódó motívumként tárgyalnak róluk. A grafikák elemzéseivel
Vajda téranalizáló megoldásainak változatosságát, illetve olvasmányélményeinek lehetséges hatását mutatom be a müveken. Kutatásom során azt vizsgáltam, hogy található-e összefüggés Vajda írásos feljegyzései (főként olvasmányjegyzéke) és munkái között. Meggyőződésem, hogy a Pepita füzetek alapján megismert, Vajdának a különböző Európán túli kultúrákhoz kapcsolódó olvasmányainak áttekintése után a kutatásban további lehetőségek rejlenek. Ez a megközelítési mód, amely szerint Vajda olvasmányainak az összevetése műveivel közel visz minket az életmű megértéséhez, nem tekinthető újdonságnak. Mándy monográfiájában több alkalommal utal Vajda „intellektuális hátterére”, gyakran hozza szóba Vajda lehetséges olvasmányélményeit konkrét alkotásokkal kapcsolatban is.

\section{Vajda Lajos térábrázolási módszereinek forrásai}

A modern kor térelméleteinek tárgyalásához kiindulópontnak tekinthető Adolf Hildebrand Das Problem der Form in der bildenden Kunst címü, németül 1893 és 1910 között nyolcszor, magyar nyelven 1910-ben másodszor megjelent kötete. ${ }^{5} \mathrm{~A}$ Pepita füzetek tanúsága alapján Vajda ismerhette Hildebrand könyvét és az abból kiinduló, a 20. század első harmadában született képzőmúvészeti térelméletek (Ernst Tross, Heinrich Wölfflin, Hans Berstl, Alois Riegl, El Liszickij) legfontosabb fogalmait. ${ }^{6}$ A tér különböző definiálásával foglalkozó elméleteknek a megjelenésével párhuzamosan a képzőművészek is elkezdik vizsgálni a tér leképezésének a lehetőségeit. A reneszánsz perspektivikus ábrázolás elvetésével új megoldásokat keresnek a térérzékeltetésre, amelyek nem csak a múvekben 
valósulnak meg, hanem ezzel kapcsolatos gondolatait sok festő írásaiban is rögzíti. Vajda ebben az értelemben nem tekinthető teoretikus müvésznek, erre utal, hogy leveleinek kivételével a megmaradt írott források nagyrészt könyvcímeket tartalmaznak. A Pepita füzetekből kiderül, hogy Vajdát az Európán túli kultúrák térábrázolási megoldásai is érdekelték. A továbbiakban az egyiptomi és a távolkeleti kultúrákra vonatkozó bejegyzéseket, elméleteket, majd Vajda múveinek az azokhoz kapcsolható kompozíciós megoldásait mutatom be.

\section{Antik egyiptomi kultúra}

Az antik egyiptomi kultúrával kapcsolatban több tétel is szerepel a Pepita füzetekben. A vizsgálódás szempontjából ezek közül az egyiptológus Heinrich Schäfer 1919-ben megjelent Von ägyptischer Kunst besonders der Zeichenkunst címü könyve ${ }^{8}$ különösen jelentős, mivel Vajda, 1937. május 2-án Júliának írt levelében meg is említi:

„Egy új könyvet vettem ki a könyvtárból, Schäfer Von ägyptischer Kunst besonders der Zeichenkunst. A könyv nagyon érdekes dolgokat tárgyal, amelyek engem főképp érdekelnek és érdekeltek azelőtt (is), a térbeliség problémáival foglalkozik főképpen, de hibája van rengeteg, főképpen az, hogy hiányzik nála a világszemléleti bázis felismerése." ${ }^{9}$

Vajda levelében ezután az eredeti német nyelvű főés alcímeket sorolja fel hosszasan (1. kép). A Levelek 1996-os kiadásában még nem sikerült beazonosítani a könyvet, ezért a kötet Vajda által kijegyzetelt tartalomjegyzéke fakszimilében olvasható a 20. oldalon. A címek sürün írottak, nagyon nehezen olvashatók, ám az eredeti tartalomjegyzék összevetésével egyértelmúvé válik, hogy Vajdát valóban a térproblémák érdekelték elsősorban. Ezt bizonyítja, hogy a könyv főcímei (nem az összes) mellett a térproblémákkal foglalkozó alcímek részletesen szerepelnek, illetve némelyiknél (alcímnél és főcímnél egyaránt) aláhúzással jelölte fokozottabb érdeklődését. A címek felsorolása után a kötet mottóját is leírja Júliának (itt is aláhúzásokkal emel ki részeket), erre a könyv további ismertetésénél még viszszatérek. Schäfer könyve, mint azt Vajda is írta levelében, főként a térbeliség kérdésével foglalkozik. Az első három rövid fejezetben Schäfer felvázolja a kor addigi ismereteit az egyiptomi művészetről, majd általánosságban ír az egyiptomi művészet jellemzőiről, a festészetről és a reliefmüvészetről. A következő három fejezetben hosszasan mutatja be a térábrázolással kapcsolatos kérdéseket. A Viszonyulás a perspektívához (Vajdánál Die Perspektive erőtelje-

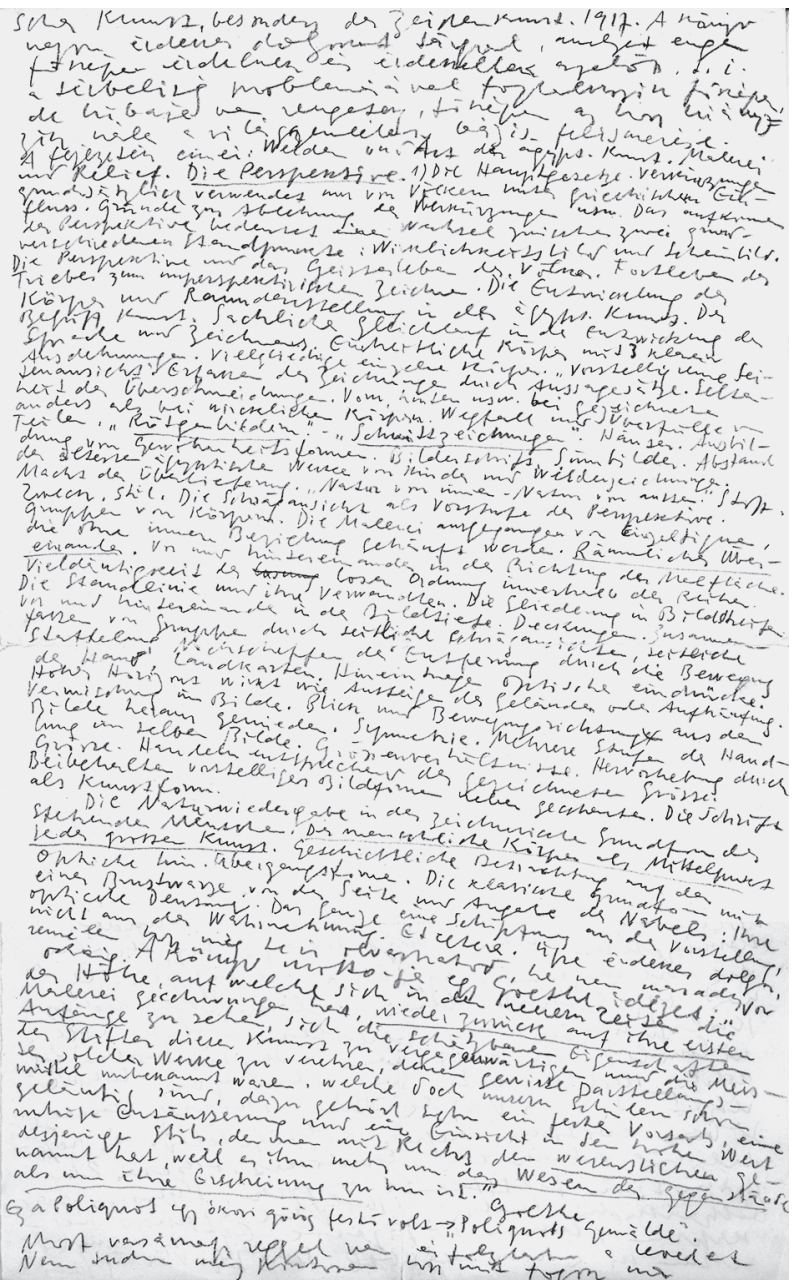

1. Vajda Lajos 1937. május 2-án írt levele Júliának. Magántulajdon

sen aláhúzva) címú negyedik fejezetben leszögezi, hogy az egyiptomi művészet tárgyalásával kapcsolatban a lineáris perspektíváról lesz szó, és három megállapítást közöl:

„1. Körper sind für den Bild undurchdringlich. Daher verdecken die näheren die ferneren, soweit beide mit dem Auge in einer Linie liegen.

2. Fernere Dinge erscheinen uns, in Höhe sowohl wie Breite, kleiner als nähere gleicher Größe.

3. Dinge in oder auf einer wagerechten Eben scheinen um so höher zu liegen, je weiter sie von uns entfernt sind, und je höher unsere Augen über ihnen stehen. ${ }^{\star 10}$

A három megállapítást együttesen a lineáris perspektíva feltételének tekinti. A második megállapítás a testek rövidülését jelenti, amely az antik egyiptomi művészetben nagyon ritkán jelenik meg. A rövidülés következetes alkalmazásának kezdete a Kr. e. 5. században a görög múvészethez köthetô, név szerint szamoszi Agatharkhosz és athéni Apollodorosz voltak a perspektíva feltalálói. 
Schäfer szerint ekkor még nem lehet matematikai tökéletességről beszélni, ahhoz a 15. században jutunk el. Véleménye szerint azok a népek, amelyek zárt kultúrában éltek, és így a görög müvészet sem hatott rájuk, nem is alkalmazták a perspektívát. Ilyen volt az antik egyiptomi kultúra is, mely az 5. században ragaszkodott hagyományaihoz. Schäfer hangsúlyozza, hogy a három megállapítás együttes alkalmazása nem a müvészi látás fejlettségére vagy fejletlenségére utal, hanem az érzéki világ visszaadásának két különböző megfigyeléséből adódik. A perspektivikus ábrázolásnál az érzéki benyomások pontos visszaadása a cél, azoknál a népeknél pedig, amelyek nem alkalmaznak rövidüléseket, a dolgok tárgyszerü jelenvalóságának ábrázolása. Ezzel kapcsolatban hivatkozik a könyve mottójául is választott idézetre, Goethe Polygnots ${ }^{11}$ Gemälde címü, 1803-as müvének egy részletére, ${ }^{12}$ amely Vajdának Júliához küldött levelében is szerepel az alábbi kiemelésekkel:

„,Von der Höhe, auch welche sich in den neuern Zeiten die Malerei geschwungen hat, wieder zurück auf ihre ersten Anfänge zu sehen, sich die Schätzbaren Eigenschaften der Stifter dieser Kunst zu vergegenwärtigen und die Meister solcher Werke zu verehren, denen gewisse Darstellungsmittel unbekannt waren, welche doch unsern Schülern schon geläufig sind, dazu gehört schon ein fester Vorsatz eine ruhige Entäußerung und eine Einsicht in den hohen Wert desjenigen Stils, den man mit Recht den wesentlichen genannt hat, weil es ihm mehr um das Wesen der Gegenstäube als um ihre Erscheinung zu tun ist."13

A test- és a térábrázolás fejlödése az egyiptomi rajzmüvészetben (Die Entwicklung der Körper- und Raumdarstellung in der ägyptischen Zeichenkunst) címü fejezetben Schäfer azokra az eljárásokra hoz példákat, amelyeket a tér és a test ábrázolásakor alkalmaznak. Az ábrázolási módokat három, általa felállított csoporton és az azokba sorolt müveken keresztül vizsgálja: egyszerü testek, többtagú testek és több egyedi testből álló csoport. Az egyiptomi müvek mellett analógiaként gyerekrajzok és primitív népek rajzai szerepelnek. Itt csak azokat az eljárásokat mutatom be, amelyeket Vajda a levelében aláhúzással kiemelt.

Az első ilyen, Vajda által fontosnak tartott fogalom a Schäfer által idézőjelben használt „Röntgenbilder" („röntgenképek”). ${ }^{14}$ Ez arra az eljárásra utal, amikor a rejtett dolgok láthatóvá válnak. A vékony, átlátszó ruha alatt látszódik az ember szíve, köldöke vagy a nemi szerve. Az egyiptomi képen a szőlőpréselők lábfejét az erjesztőkád oldala kitakarná, mégis láthatóak, illetve a másik példán a gabonatároló-edények tartalmát látjuk (2. kép). Ezzel az eljárással Schäfer korábban bemutatott három sza-
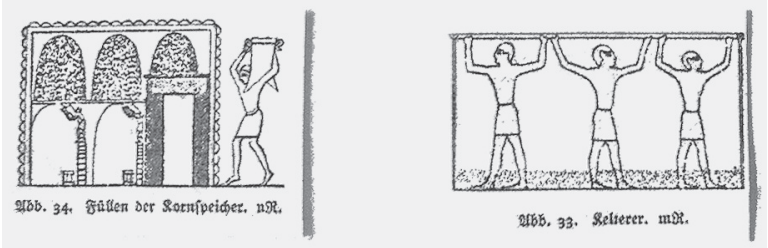

2. Heinrich Schäfer könyvének (Von ägyptischer Kunst besonders der Zeichenkunst. Leipzig 1919) 33-34. ábrája

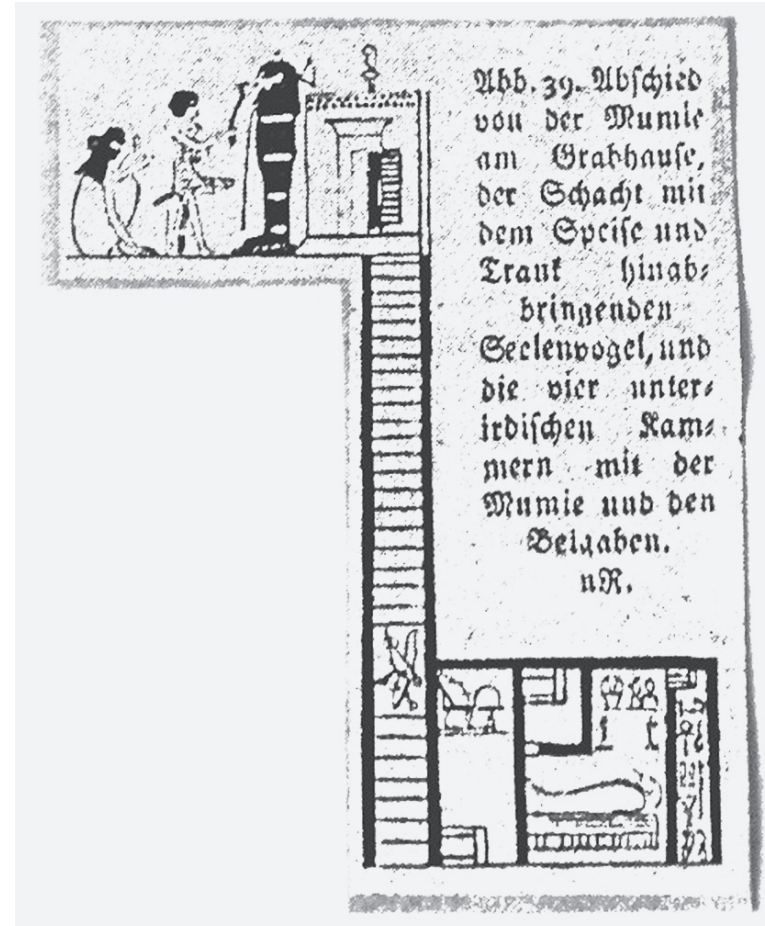

3. Heinrich Schäfer könyvének (Von ägyptischer Kunst besonders der Zeichenkunst. Leipzig 1919) 39. ábrája

bálya közül a testek átláthatatlanságára vonatkozó első szabályt szegik meg.

A levélben kiemelt másik kifejezés, a szintén idézőjelben használt „Schnittzeichnungen”, amit „,metszeti rajzoknak" lehetne fordítani. ${ }^{15} \mathrm{Az}$ ábrázolásokon a motívumok, dolgok metszeti rajzokból, illetve különböző nézőpontokból ábrázolt felületekből épülnek fel. A Schäfer által leírt Halottaskönyv egyik részletén a vízszintesen jelölt talaj fölött a sírház külső nézetét látjuk nyitott ajtóval (3. kép). A sírházból a föld feletti részen is ábrázolt akna fut a mélyben fekvő sírkamrába. Az aknát keresztmetszetben mutatja, a mélyben elhelyezkedő négy részre tagolt sírkamrának viszont az alaprajzát látjuk. Az alaprajzban a múmia és a vele eltemetett eszközök teljes nézetben jelennek meg. A nézőpontváltások, az alaprajz és a metszeti rajz szintézise az ember adott dologra vonatkozó tudásának felhasználásával válik értelmezhetővé.

A harmadik aláhúzott terminus a „Räumlisches Übereinander", azaz téri egymásfölöttiség, amely 


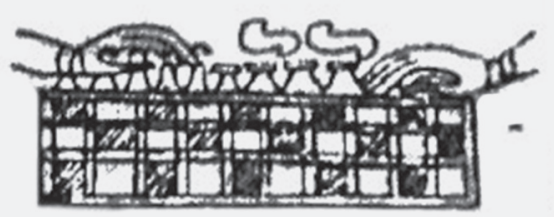

366. 63. Brittiplel mil Etcillen. Daraber 23 arfettu\&del. nR. (Rlubidnitt.)

4. Heinrich Schäfer könyvének (Von ägyptischer Kunst besonders der Zeichenkunst. Leipzig 1919) 63. ábrája

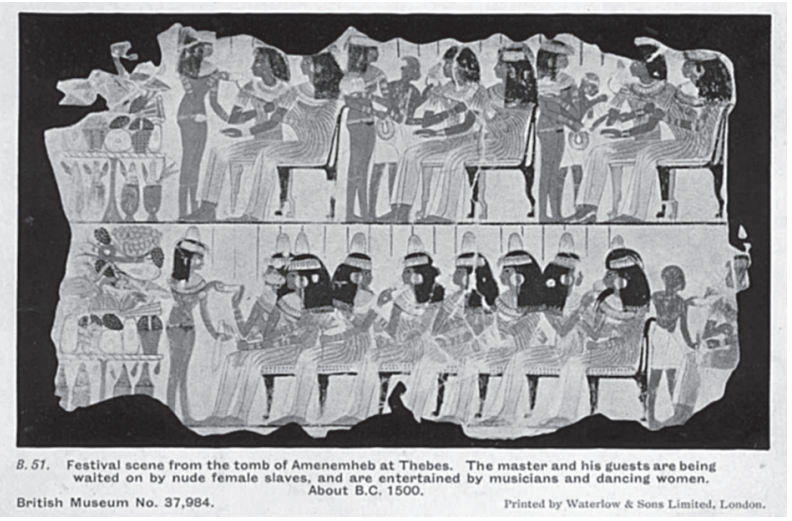

5. Vajda Lajos 1936. június 22-én Júliának írt levelével elküldött képeslap. Magántulajdon

az egyiptomiaknak arra a térábrázolási megoldására utal, amikor az egyik tárgy a másikon helyezkedik el. ${ }^{16} \mathrm{Az}$ egyik szemléltető példán a játéktábla felülnézetből, míg a bábuk a tábla peremén teljes nézetből láthatók (4. kép). Schäfer hangsúlyozza, hogy ebben az esetben a bábuk pontosan illeszkednek a peremhez. Az egyiptomi történelmi kor kezdetéről olyan megoldások is ismeretesek, melyeken a felső tárgy az alsó felett lebeg.

Júliának írt, fent idézett levelében Vajda megjegyzi, hogy hiányolja a könyvből a világszemléleti bázist. Ennek oka az lehet, hogy ő a különböző térábrázolási megoldások magyarázatát az adott kultúra világszemléletének megismerésével együtt vizsgálta, Schäfer viszont példáit nem hozza összefüggésbe az egyiptomiak világszemléletét meghatározó túlvilágba vetett hittel, illetve a mitológiával.

Vajdának az egyiptomi kultúra iránti érdeklődése már a Párizsban töltött időszakában (1930-1934) is kimutatható. Kozák Gyula 2011 novemberében megtalálta a hagyatékban azt a képeslapot, amelyet Vajda 1936. június 22-én küldött el Júliának (5. kép): „Itt küldök mellékelve egy egyiptomi reprodukciót, melyet még Párizsból hoztam magammal, most előkerült, és elküldöm néked."17

A képeslapon a tanulmány témájának szempontjából jelentős építészeti elem nem látható, de a vízszintes vonallal jelzett talajszinthez rögzített figurák ábrázolásában az egyiptomiakra jellemző legnagyobb felületek elve megfigyelhető. Tehát ebben az esetben is, a térábrázolási megoldásokhoz hasonlóan, egy elvont rendszer érvényesül. Az egyiptomiak úgy ábrázolták a világot, ahogy az emlékképeikben, tapasztalataikban megjelent, és nem a látvány mimetikus visszaadása volt a céljuk.

Az ábrázolási módokban szembetűnő a hasonlóság Vajda szentendrei városképeinek egy részével; a transzparencia, a nézőpontváltások ismert fogalmak Vajda műveivel kapcsolatban, ezt az elemzéseken keresztül fogom a későbbiekben szemléltetni.

\section{Távol-keleti kultúrák}

Az antik egyiptomi múvészet mellett a keleti miniatúrafestészetet vetettem össze Vajda szentendrei városképeivel. Ez a Vajda-életművel összefüggésben eddig nem tárgyalt kultúra arányaiban meglepően sokszor előfordul a Pepita füzetekben; különösen hangsúlyos a kínai és a perzsa festészet, amint az a tematikus bibliográfiából is kiderül. Ezekben a tudományos munkákban ritkán esik szó a térábrázolásról. Említésszerüen találkozhatunk azzal az európai szemléletü megjegyzéssel, amely a perspektíva hiányára utal.

A Vajda-hagyatékban megtalálható a párizsi Bibliothèque Nationale gyưjteményét bemutató 1925-ös tárlat katalógusa. ${ }^{18}$ A kiadványt végiglapozva felkeltette a figyelmemet egy kép: egy Rashid alDin (14. századi perzsa történetíró) krónikájához a 14. században készült perzsa miniatúra 15. századi másolata (10. kép). ${ }^{19}$ A festmény vonalstruktúrájának alapos megfigyelésekor hasonlóságot észleltem Vajda szentendrei városrajzaival. Vajda a katalógus képjegyzékében csak ezt a művet jelölte meg. A jelölés biztosan hozzá köthető, hiszen ugyanezzel a tintával szerepel a katalógus elején a neve.

Vajda által írt forrást erre vonatkozóan nem ismerünk; a keleti múvészettel kapcsolatban nem értekezik külön a leveleiben, a papírok és a cédulákra kimásolt jegyzetek sem erről szólnak, de a hagyatékban őrzött 1925-ös kiadványban látható perzsa miniatúrának a megjelölése hipotetikusan irányadó lehet. ${ }^{20}$ Természetesen itt is figyelembe kell venni azt a tényt, hogy Vajda könyvei, jegyzetei töredékesen maradtak ránk. 
A perzsa miniatúrafestészettel kapcsolatban Szántó Iván orientalista művészettörténész hangsúlyozza, hogy az iszlám festészetnek nincsenek a perspektívára vonatkozó saját elméletei, a miniatúrákat nem az anyagi világ valósághű ábrázolása határozza meg. ${ }^{21}$ Szántó megjegyzi azt is, hogy a modern és avantgárd művészek a tiszta színek dominanciája és a perspektíva hiánya miatt lelkesedtek ezekért a miniatúrákért. Ez utóbbi Vajda müvein is érezhető, de ennél jelentősebbek lesznek a formai hasonlóságok, amelyekre még rámutatok.

A tematikus bibliográfiából kiderül, hogy Vajda érdeklődése nem csupán erre a két kultúrára koncentrálódott. A szentendrei városrajzok térábrázolásával, komponálásával kapcsolatban azonban ezek tüntek jelentőseknek, amit elemzéseken keresztül kívánok szemléltetni.

\section{Az egyiptomi müvészet hatása}

A Hegyi házak (6. kép) vonalszövedékeiben felfedezhető a település lakóházainak egymás melletti és egymás mögötti helyzete. Ez a rajzi sűrítés a tár-

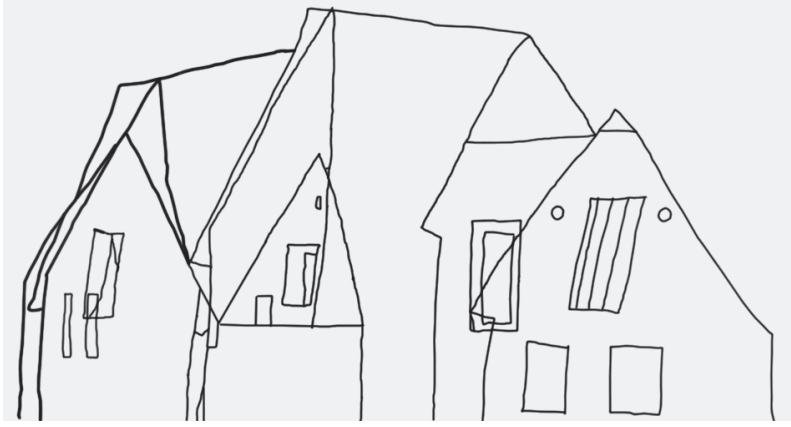

6. Vajda Lajos: Hegyi házak, 1936.

Papír, ceruza, 31,5×47,5 cm. Magántulajdon (MS 1936/78) (MS = Mándy Stefánia: Vajda Lajos. Budapest 1983, az œuvre-katalógus száma)

gyak, az épületek kapcsolatára utal, a közelség érzetét kelti. Nincs horizontvonal, az egymás mögött álló épületek homlokzatai áttünnek egymáson. Az egyiptomi transzparens ábrázolásokhoz hasonlóan a térmélységet Vajda nem a perspektíva szabályait követő vizuális megoldásokkal érzékelteti, hanem „fogalmilag” ragadja meg. Természetesen itt nem

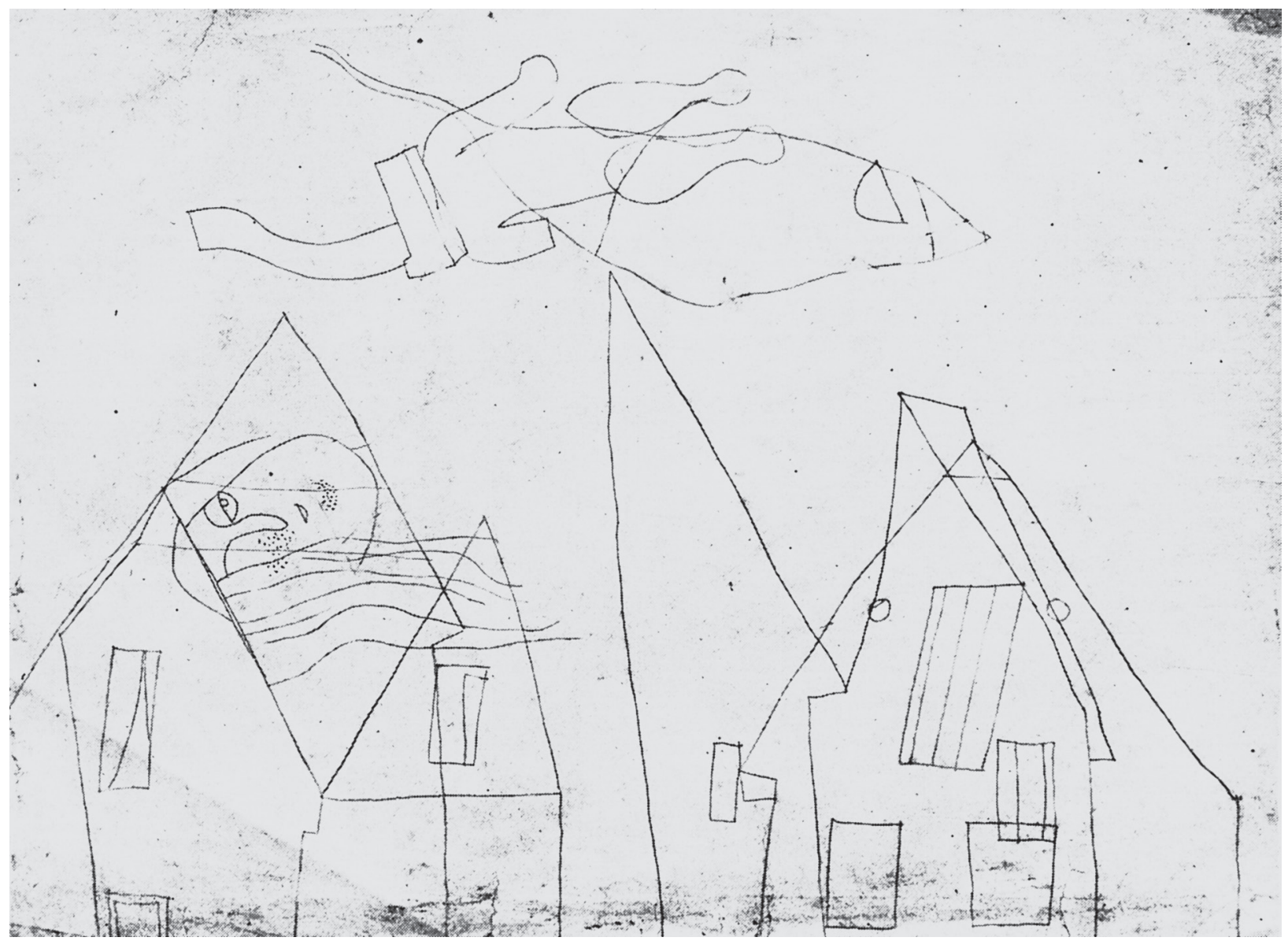

7. Vajda Lajos: Házak felett, 1937. Papír, ceruza, 36,6×46,3cm. Magántulajdon (MS 1937/2) 


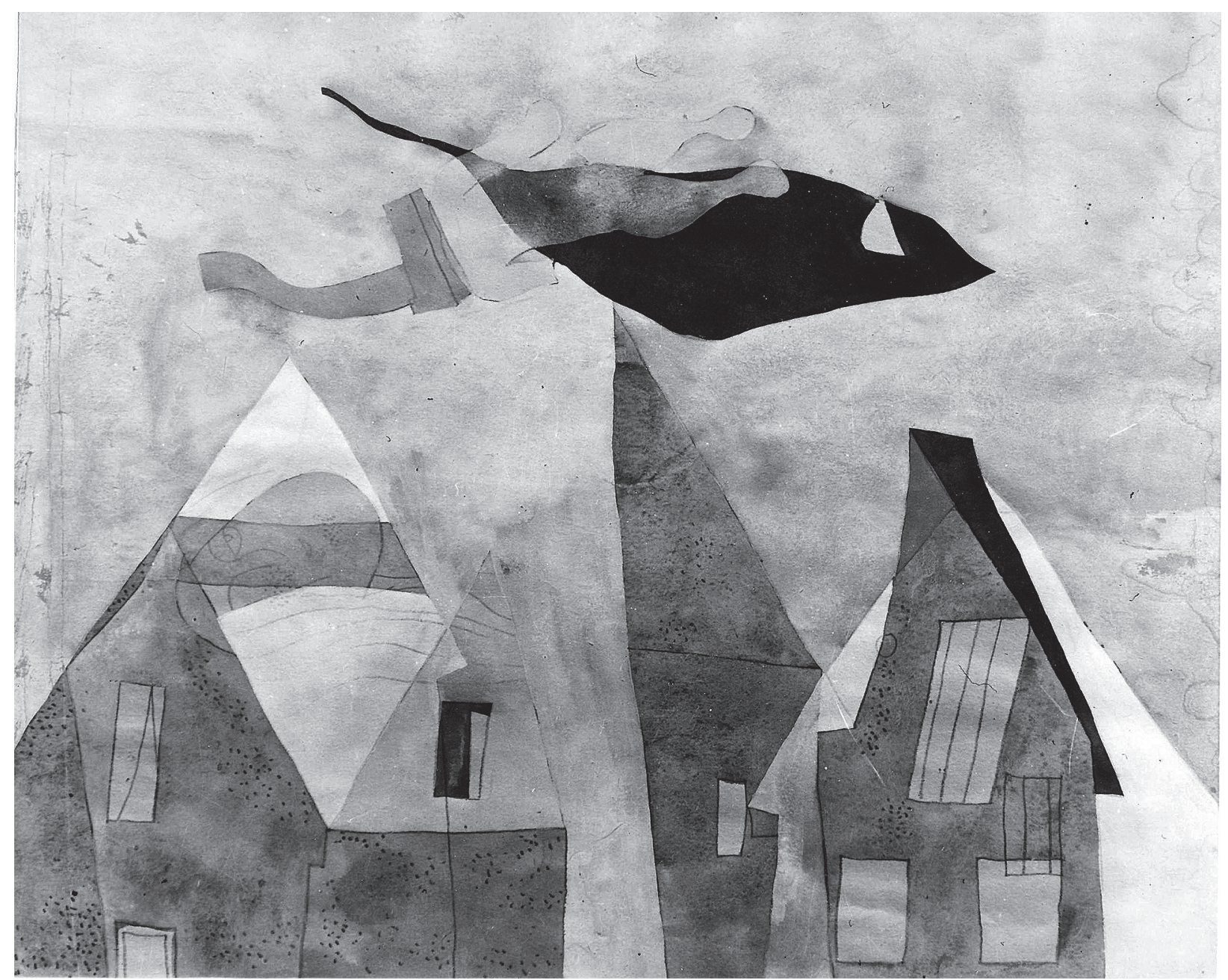

8. Vajda Lajos: Házak felett, 1937. Papír, tempera, 35,5×43,5 cm. Magántulajdon (MS 1937/90)

egy következetes rendszerről van szó, az ő gondolkodásmódja nem azonos az egyiptomi kultúráéval, de felfedezhetünk kifejezésmódbeli utalásokat. Megmaradt életművében ehhez a rajzhoz szorosan kapcsolódik két másik munka, a Házak felett címú kép vonalrajzos (7. kép) és tempera (8. kép) variánsa. A három munka összevetésével, a vonalstruktúrák apró változásainak megfigyelésével közelebb kerülünk a művész térábrázolási kísérleteinek megértéséhez.

A Hegyi házak című rajzon látható jobb oldali két ház viszonya egyértelmünek tűnik; a takarás miatt tudjuk, hogy az alacsonyabb ház előrébb helyezkedik el, azonban a hátsónak az ablaka megjelenik az elülsőnek az oromzatán. A másik két müről ez a ház teljesen eltűnik, csak utalásszerüen egy apró részletben bukkan fel: az oromzat aljánál lévő tetőkiszögellés alatt az első rajzon transzparenciában megjelenő ablaknak a bal alsó sarkát láthatjuk. Ennek a kis elemnek a továbbvitele, megjelenése a későbbi rajzokon is bizonyítja, hogy Vajda tudatosan egy- másra építette munkáit. Az ablak sarka a kiinduló rajzon megfeleltethető még a valóságnak, tehát ábrázolt forma, míg a később keletkezett munkákon már csak töredékében, kompozíciós motívumként van jelen. Az a tény, hogy ez a kis elem újra és újra feltünik, mutat rá arra, hogy nem véletlenszerü, az átrajzolás során bekövetkezett technikai hibáról van szó, hanem tudatosan használt, jelentéssel bíró részlete ez a müveknek. A megfigyelt látvány rögzítése helyett itt már a ritmus, a felület osztása, a pozitív-negatív formákkal való komponálás a cél. Az ábrázoló művészetben az ábrázolt dolog megjelenését értelmezzük pozitív formaként, Vajda rajzain a házak (kontúr)vonalakkal válnak el az őket körülvevő tértől. A kontúr tehát választóvonal, egyszerre határozza meg a pozitív és a negatív formát. Vajda transzparens képein ez a képlet feloldódni látszik, az egymásra rétegzett pozitív formák esetében felcserélődhetnek a funkciók, az a felületrészlet, amely az egyik ház viszonylatában pozitív formaként szerepel, egy másik, egymáson elhelyezett térszeletet 


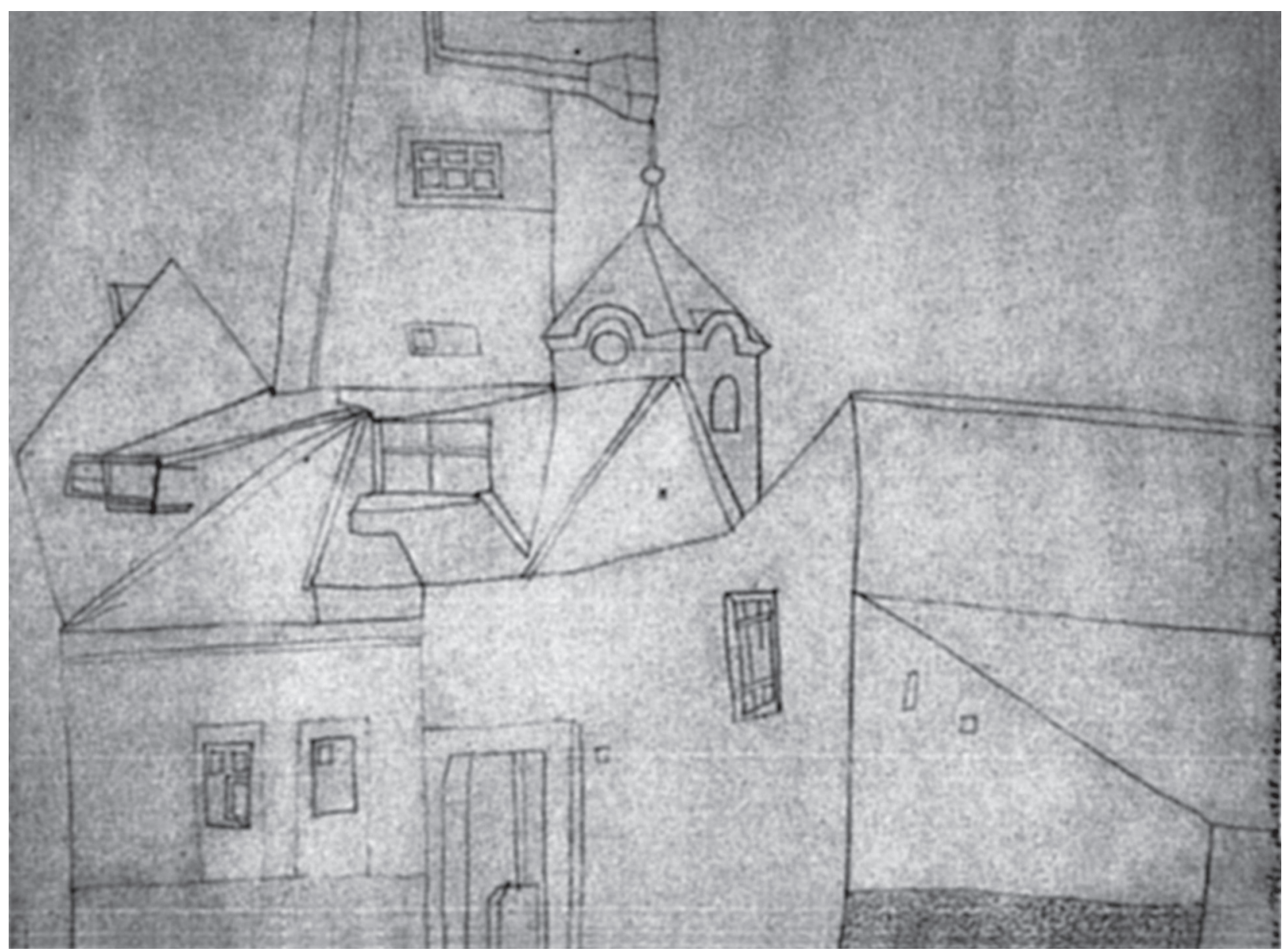

9. Vajda Lajos: Háztetók toronnyal, 1936.

Papír, ceruza, 23,6×31,5 cm. Magántulajdon. (Hátlapon: Oszlop petróleumlámpával, 1937; MS 1937/27)

vizsgálva már negatív formaként értelmezhető. A múvész ezt a térjátékot, ezt a feszültséget a kompozíció festett változatán is fenntartja. A temperakép jobb oldalán látható három ház térbeli helyzetét könnyű értelmezni. Hozzánk legközelebb a legkisebb, keskeny, bal oldalán megtört vonallal kialakított ház áll. Mögötte a világos színü, szélesebb épület helyezkedik el, majd leghátul a féloromzatú építmény van. Ennek az állításnak az egyértelmüsége megkérdőjeleződik, ha alaposabban megvizsgáljuk a házakon elhelyezett ablakokat. Nem dönthető el, hogy melyik ablak melyik épülethez tartozik. A világos ablakok éppen úgy tartozhatnak az elöl lévő sötétebb tónusú házhoz, mint a világoshoz. A két másik rajz alapján sejthető, hogy ennek az épületnek az ablakai. Ugyanakkor a vonalasan megjelenő, a jobb oldali ablakba belógó sávozott téglalap forma értelmezéséhez nincs semmilyen támpontunk, mind a két lakóhelynek lehet a része. Az épületek megfestettségük, színnel kitöltött felületük ellenére transzparensek. A képek jobb oldalán megjelenő transzparencia háromrétegüsége nem a klasszikus előtér-középtér-háttér hármas tagolá- sú térszemléletet képezi le. A térviszonyoknak, az épülettömegek együttes hatásának egy teljesen új megjelenési formáját mutatja. Ezt a hatást erősítik a képek bal oldalának épületrajzai. Annak ellenére, hogy a Hegyi házak esetében a három magas oromzatot Vajda vonallal köti össze, és ez a képfelületen jelentős elem, mégsem teremti meg az egész képen belüli egységes, valós térérzetet. A rajzon szereplő összes ház a lap aljához illeszkedik. A horizont hiánya, a rövidülések és a távolság érzékeltetésének elvetése ellenére felismerhető a térmélység. A transzparencia Vajdánál ugyanúgy, mint az egyiptomi müvészet esetében, arra szolgál, hogy a tudottat, a hétköznapi életünkből tapasztalat útján megismertet felidézze. Nem a látvány általi benyomás megragadása a cél. A kép befogadásának mechanizmusa a transzparens épületrajzok esetében ezzel éppen ellentétes, az európai mimetikus művészeti hagyományoktól eltérően a tudásból, a fogalmi gondolkodásból indul ki. A rajzszövet felfejtése közben az értelmezés során kapjuk meg a térérzetet.

A Háztetók toronnyal címü rajzon (9. kép) a transzparencia mellett a Schäfer könyvéből meg- 
ismert, az egyiptomi kultúrára jellemző másfajta ábrázolási módok („téri egymásfölöttiség”, „metszetrajzok") is megfigyelhetőek. A különböző nézőpontokból ábrázolt épületek kiterjedésének iránya, az egymáshoz viszonyított helyzetük Szentendre belvárosának sajátos elrendezésére utal. Az előtérben látható három homlokzat a lap aljához illesztett elhelyezés miatt látszólag egy síkban fut, azonban a középső és a jobb oldali épület oldalhomlokzatainak redukált formái is megjelennek, így érezteti Vajda a szentendrei kis utca szabálytalanságát, enyhe kanyarulatát. A rá jellemző sürítés a kompozíció közepén tapasztalható, ahol Vajda a transzparencia módszerével a középső ház mögötti épületeket jelzi. Ugyanakkor, a templomtornyot csak részben takarja ki az előtte álló épület oromzata. Ugyanez épület nyeregtetőjén áttetszik a torony felénk eső oldalfalának a bal éle, amelynek meghosszabbított vonala a torony párkányzata fölött tovább nyúlik. Ez a vonal a képsíkra merőlegesen elfordított homlokzat meghatározó elemévé válik. A homlokzat elforgatásával Vajda a távolban futó, képsíkra merőleges kis utcára utalhat. A kis utca távolságának az észlelésére Vajda formajátéka különböző lehetőségeket biztosít. A torony bal éléből tovább futó vonal a képsíkra merőlegesen ábrázolt homlokzat talpvonalát is jelentheti. Ebben az esetben a kis négyzetekkel tagolt felület ajtóként értelmezhető. Az említett vonal és a toronynak a vele párhuzamos csúcsdísze között kialakult geometriai forma az elforgatott ház lábazatát is jelölheti. Így a ház megnövelt méretével közelebb kerül, és a négyzetekkel tagolt ajtó ablakká válik. A téri játék a tetônél is folytatódik, a nyitva hagyott negatív forma a végtelen tér érzetét kelti.

Eddigi elemzéseim során az egyiptomi térábrázolás „elvont” megközelítésének sajátos megfogalmazásait szemléltettem Vajda városképein. A továbbiakban a perzsa múvészet felől közelítem meg múveit. Hipotézisem szerint a miniatúrák formaalakítása érdekelhette Vajdát.

\section{A perzsa miniatúrák hatása}

Rashid al-Dinnak a korábban említett párizsi katalógusban Vajda által megjelölt alkotása az 1258-as bagdadi csatát ábrázolja (10. kép). A Vajda-életmüben nem találunk történelmi eseményeket elbeszélő munkákat, feltételezhetjük tehát, hogy érdeklődése a miniatúrával kapcsolatban elsősorban az építészeti tér ábrázolási megoldásaira, formakomponálásra irányult. A térstruktúra egyértelműen látszik, ha indigópapír segítségével kiemeljük a miniatúra kompozíciós vázát (11. kép). Ez a megoldás, az átkopírozás, a lényegesnek tünő elemek kiemelése és egy vonalstruktúrában való megjelenítése nagyon közel áll Vajda gondolkodásmódjához és munkamódszeréhez. Az eredeti munka átkopírozott verzióján feltünővé válik az épületek egymáshoz viszonyított arányának a torzulása, a kompozíció érdekében nyitottan, tehát nem zárt formaként szereplő házrészletek, a különböző nézőpontokból látott térrészletek sűrűn egymás mellé helyezése, a geometriai formákként megjelenített épületrészletek ritmusa.

Ezek a megállapítások igaznak tünnek Vajda Péter-Pál templom címü 1937-ben készült rajzára (12. kép) is. A templom körül megjelenő házak esetében megállapíthatatlan, hogy az épületek mekkorák egymáshoz képest. A képen nem a pontos arányrendszer megjelenítése, hanem a sürítés kifejezése lehet a cél. A konkáv sokszögek, a parallelogrammák, a trapézok, a háromszögek csak utalnak a házakra, de nem ábrázolják az épületeket. Érzékelhetjük a tömegüket, de pontos térbeli elhelyezkedésükről, formájukról nem informál bennünket ez a rajz. A bal oldalon félbehagyott alakzatoknak, a képszélekre kifutó vagy megszakadó vonalaknak szerepük van, éppen úgy, mint a perzsa miniatúra esetében; egy eltérő téregységet jelenítenek meg. A tér nemcsak az épületek tömegét és az őket körülvevő levegőt jelenti, hanem az épület belsejében lévő térre is utalás történik. A külső és a belső tér egyaránt megjelenik a rajzon. A külső térből a belső térbe való átjutás valamilyen épített konstrukción keresztül, legkézenfekvőbb esetben egy bejárati lépcsőn történik. Ebből a szempontból kiemelt szerepe van a Ház a Munkácsy utcában címú munkának (13. kép). A kép centrumában elhelyezett, geometrizáló formákra bontott lépcsőt egyszerre több nézőpontból látjuk. Vajda nem egy ábrázolási metódust követ, nem egy fix pontból rajzol meg egy lényegében vetített képet, hanem különböző téri helyzetekből tárja elénk az ábrázolt tárgyat, jelen esetben a lépcsőt és környezetét, egyszerre több térszeletet, térkivágatot helyez egymás mellé. Ezt a hatást erősíti az, hogy a föld síkjának töredezettsége és az épület alja nem párhuzamos a lap élével. A házba bevezető ajtó nagysága és az elénk táruló tagolt belső tér mind arányrendszerében, mind kidolgozottságában határozottan eltér a homlokzat sematikus, leegyszerűsített formanyelvétől. Éles a különbségtétel. A belső tér a rajzon belül nagyon kis helyet foglal el, de hangsúlyos, felveti a házban lévő helyiségek kiterjedésének meglétét. A külső és a belső tér egyszerre jelenik meg, éppúgy, mint a perzsa miniatúrán, az arányok eltolásával és a nézőpontok, ábrázolási rendszerek variálásával.

A Pepita füzetekben szereplő, a témával kapcsolatos könyveket átnézve és azokat összevetve 


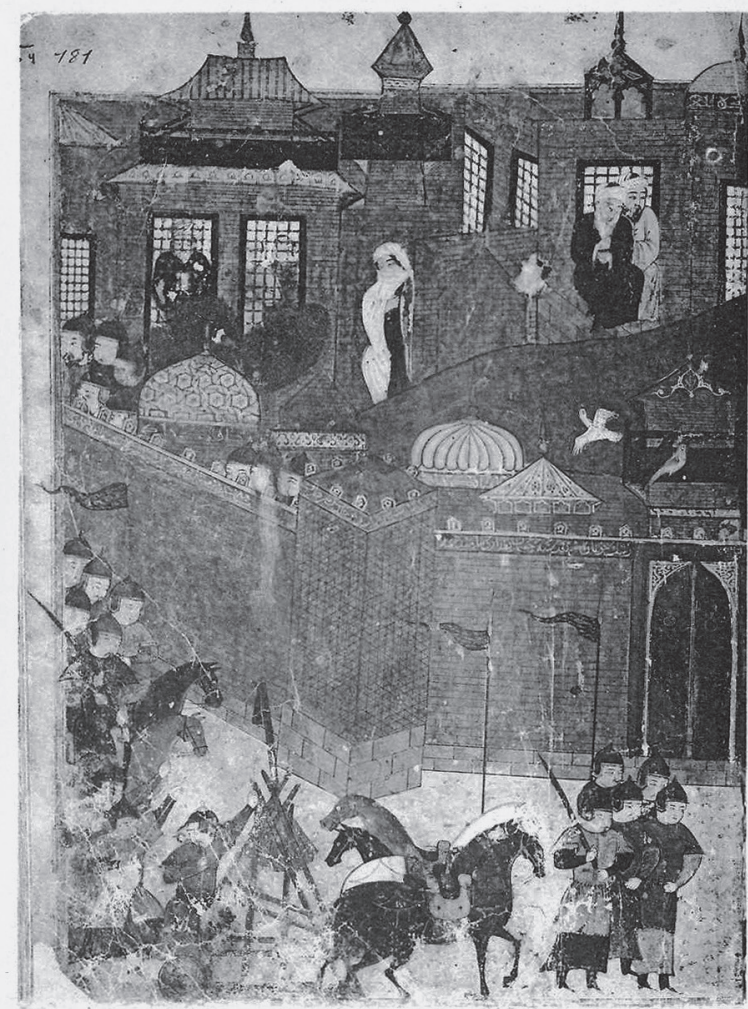

Rasuid AD-Din. - Histoire des Mongols.

Le Siège de Baghdad. Tauris $1315\left(N^{\circ}, 15\right)$

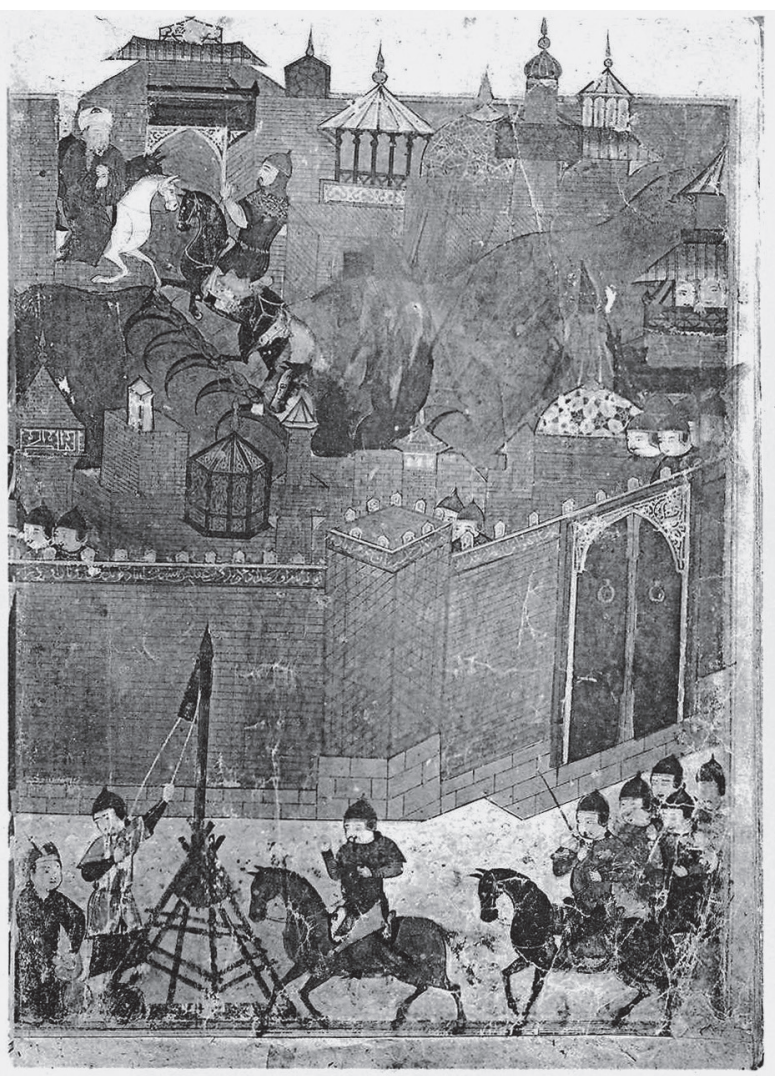

RA\&HID AD-Din. - Histoire des Mongols. Le Siège de Baghdad. Tauris $13,5\left(\mathrm{~N}^{\circ}, 5\right.$

10. Rashid al-Din: A bagdadi csata címü, 14. századi perzsa miniatúrának a 15. századi másolata. Catalogue des manuscrits à peintures, estampes, médailles, monnaies, objets d'art, livres et cartes (Bibliothèque Nationale, Paris 1925) 22. képe

Vajda grafikáival további kompozíciós hasonlóságra lettem figyelmes, melyre a perzsa miniatúrafestészetnek még két másik darabját szemléltetem példaként. Az egyik az 1463-as Majnūn haldoklik Laylā sírjánál címủ miniatúra (14. kép); ${ }^{22}$ a másik a 16. század első felében iskolateremtő mesternek,

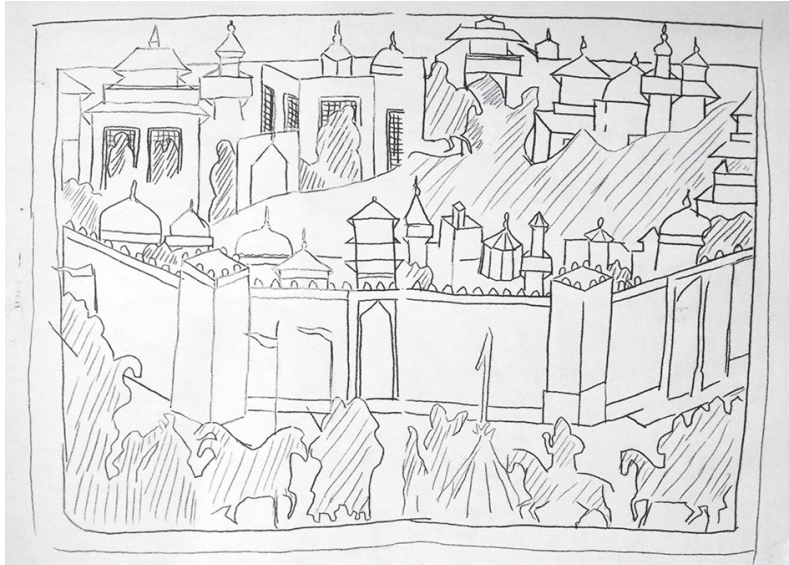

11. A 10. kép a szerzó által indigóval átrajzolva
Bihzādnak a Sikandar és a hét bölcs címü 1494-es müve (16. kép). ${ }^{23}$ Mindkét képen az épület ad keretet a narratívának. Az események az épületen belül és közvetlen közelében, kívül zajlanak. A kint és a bent többször jelenik meg együttesen egy adott kompozícióban. Az épületnek központi szerepe van. Több nézőpontból láthatjuk ugyan, de minden szereplő, minden tárgy, az összes képi elem hozzá viszonyított. Az első kép esetében a keret nemcsak fogalmiként, hanem konkrétan, vizuális jelként is megjelenik a képen. A szöveget és a jelenetet egyértelműen egy építészeti elem, az erkély szegélyének a folytatása fogja körül. Az erkély maga kilóg a szöveg és a kép téglalap alakú egységéből, kiemelt helyzetben van, eltér a lap többi részétől, de önmagában konzekvens téregységet jelöl. Itt érzékelünk térmélységet, magasságot, épület és figura közötti arányrendszert. Az erkélyen három figura áll, ők a kettős jelentésű kereten (korláton) belül helyezkednek el. Az erkély (a képen látható valós helyzete szerint) fölötti, de az európai kultúrkör felől értelmezve mögötti három fej azonban egy határral 


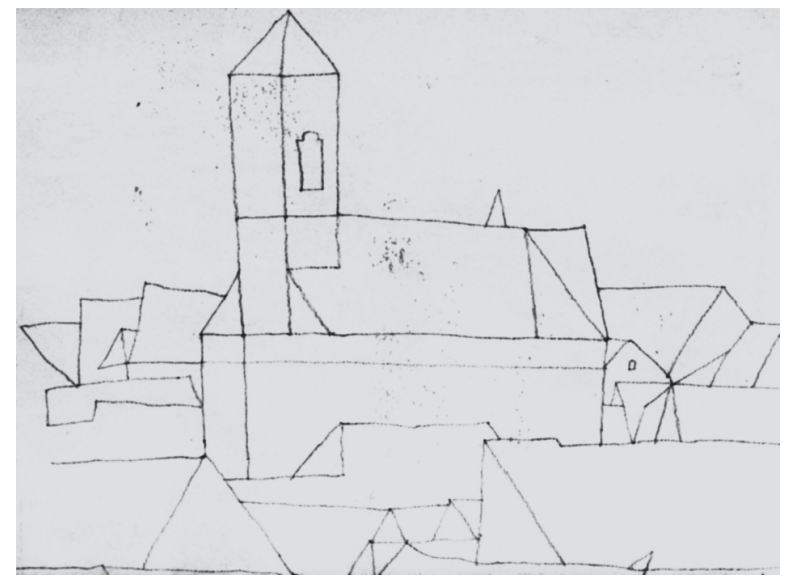

12. Vajda Lajos: Péter-Pál templom, 1937.

Papír, ceruza, $22 \times 29 \mathrm{~cm}$. Magántulajdon

(mely egyben keret és korlát is) el van választva a képtértől. Jelenlétüket értelmezhetjük egy újabb térnyitásként is. A zártság és a nyitottság, a külső és a belső tér közötti váltások jellemzik Bihzād képét is. Ezen a munkán is megjelenik egy épületrészlet, mely elem a lezárásával kilép a téglalap formátumból. Ugyanakkor a kép jobb alsó sarkában feltünik egy befejezetlen, ezáltal értelmezhetetlen építészeti elem. Megállapíthatjuk, hogy a perzsa miniatúrák formája nem a narratívának helyt adó épület valós formáihoz igazodik. A festmények készítői nem épületeket, nem teret jelöltek, hanem helyszínt jelenítettek meg. A kompozíciót ennek vetették alá. A narratívához kapcsolódva indokolt esetben hozzátoldhattak a szigorúan téglalap alakú kerethez akár egy külső, akár egy belső térrészletet. Ez a térrészlet a cselekmény fontos helye, tehát az ábrázolt helyszín része. A helyszín ebben az esetben tehát olyan külső és/vagy belső térként definiálható, ahol az élet eseményei zajlanak. Vajda átvesz bizonyos elemeket a perzsa múvészetből. Nagyon sok rajzán megjelenik a keretezés, és egyben ebből a keretből való kilépés, a hozzátoldás és az elhagyás is.

Két ház kerítéssel címü rajzán (15. kép) is megfigyelhetjük ezeket a jellegzetességeket. A közel szabályos négyszögü, a fő motívum részeiből kiinduló körberajzolást és a kép jobb szélén ehhez a struktúrához szervesen kapcsolódó, de ugyanakkor ebből a rendszerből ki is lépő, ezáltal egy új teret nyitó épületrészletet. A frontálisan, rövidülések nélkül ábrázolt homlokzatok mellett ez a jobb oldali forma

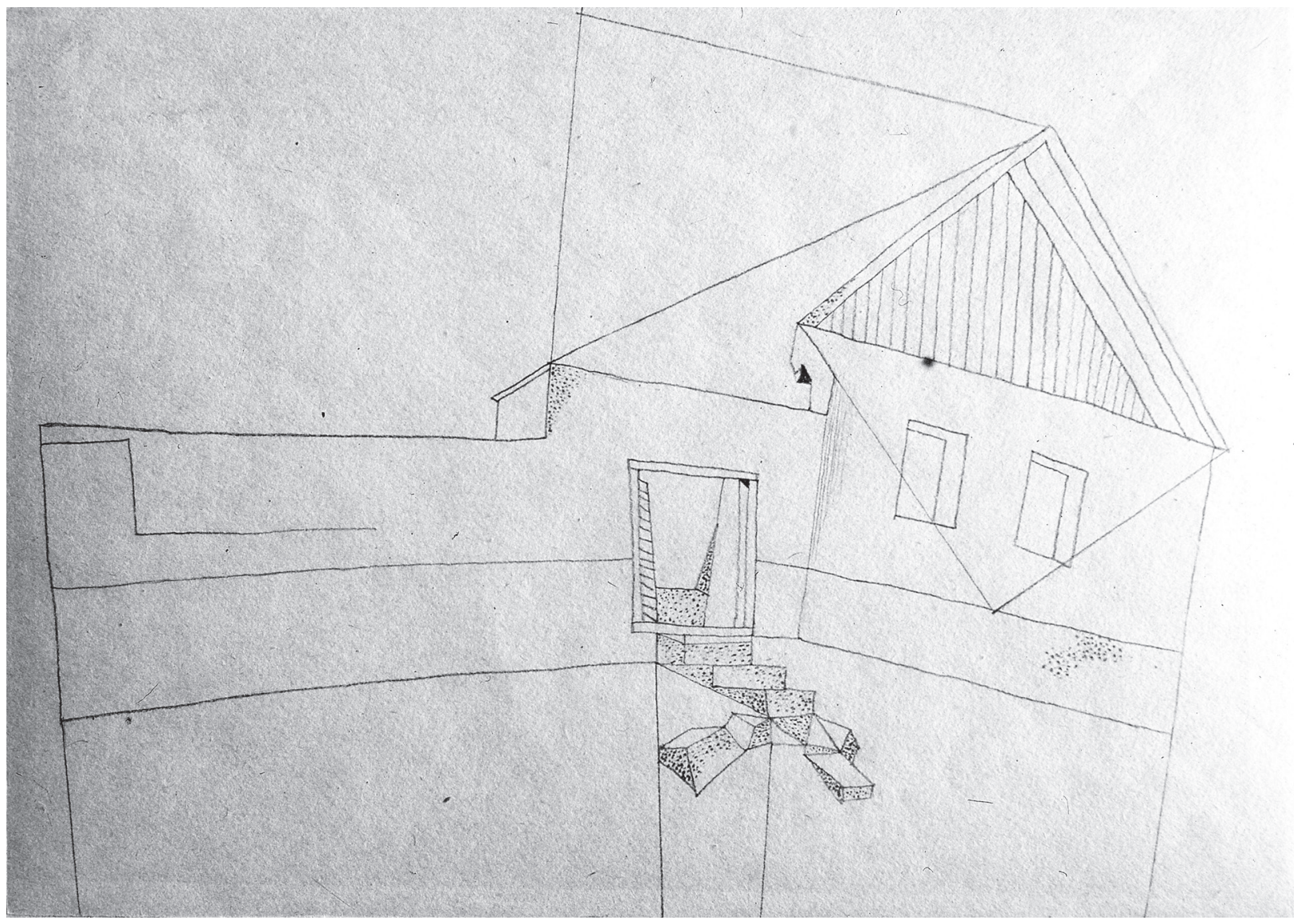

13. Vajda Lajos: Ház a Munkácsy utcában, 1936.

Papír, ceruza, 31,5×47 cm. Vajda Lajos Múzeum, Szentendre, ltsz.: 83.33. (MS 1936/6) 


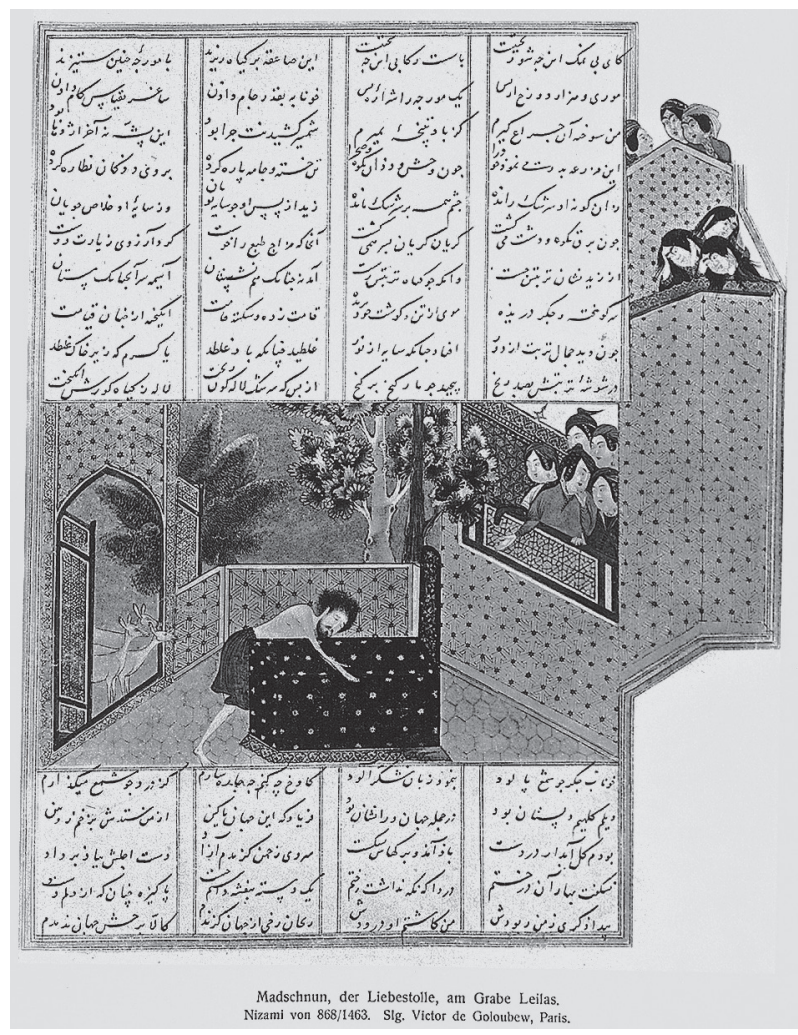

14. Majnūn haldoklik Laylā sírjánál, 1463. Miniatúra. Chester Beatty, Dublin, P137, fol.131b.

Philipp Walter Schulz könyvének (Die persisch-islamische Miniaturmalerei, Leipzig 1914) 42. képe

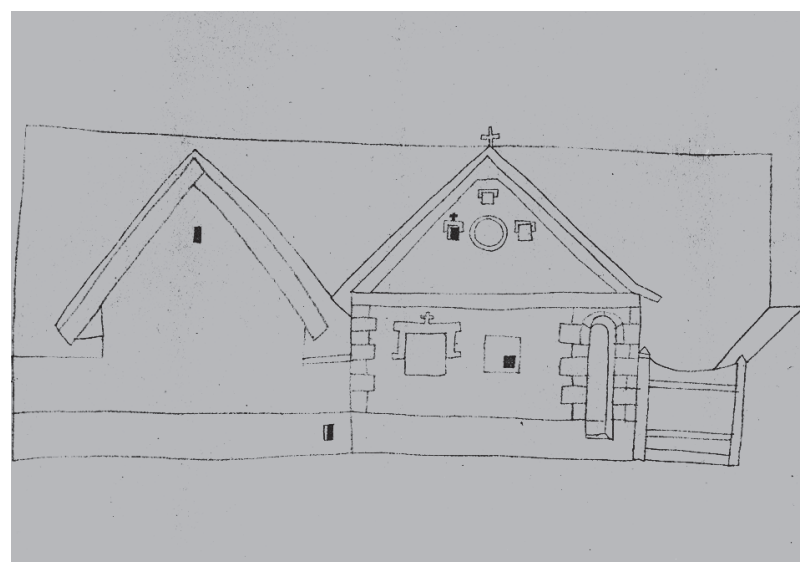

15. Vajda Lajos: Két ház kerítéssel, 1935. Papír, ceruza, $20 \times 30$ cm. Magántulajdon. (MS 1935/38)

kifejezetten felidézi a térmélységet annak ellenére, hogy nem tudjuk pontosan értelmezni, mit is jelöl valójában. Éppen úgy lehet a kapu melletti kőfal (annak iránya és vastagsága) megjelenítése, mint az utcafront következő eleme, egy nyári konyha vagy egy kisebb ház rövidülésben látható tetejének ábrázolása. A forma mindenképpen térmélységet (vastagságot) jelöl. A síkban ábrázolt homlokzatokon megjelenő ablakok, ajtók, díszítőelemek, éppen

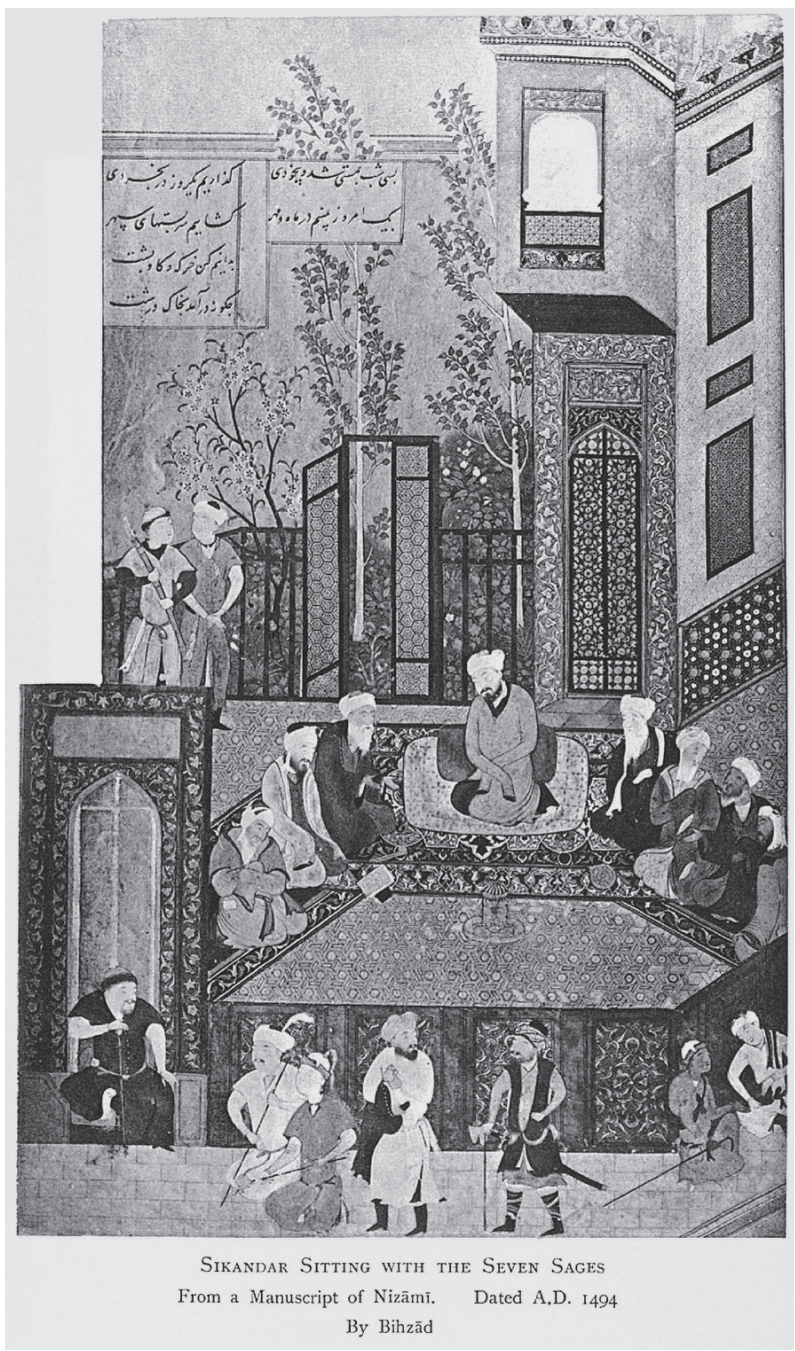

16. Bihzād: Sikandar és a hét bölcs, 1494. Miniatúra, British Library, fol.214r, Or6810. Fredrik Robert Martin könyvének

(The Miniature Painting and Painters of Persia, India, and Turkey from the 8th to the 18th Century. London 1912) 72. képe

úgy, mint a perzsa miniatúrákon ritmikusan osztják a fó formákat, és helyenként, a falvastagság jelölése mellett utalásokat észlelhetünk a mögöttes térre, a lakóépület belsejére. Egy ház fala tehát térelválasztó szerepben van, egyrészt a külvilágban kijelöli az épület téri helyzetét, másrészt körülölel egy belső, más arányrendszerben érzékelhető teret. Ez a kettősség, a kétféle arányrendszer együttes megjelenése az európai kultúrkörben nem terjedt el. Az épületek vagy városképként jelennek meg, vagy önálló belső terek szerepelnek a munkákon, vagy egy kitekintést ábrázolnak az ablakon keresztül a belső térből (ezeken az ábrázolásokon azonban nem látszik az épületek külvilágban elfoglalt helye). Az európai tradíciókból ismert isteni tér megjelenítését is egyedi módon oldja meg Vajda ezen a képen. Feltünő, hogy a kereszt motívum háromszor is szerepel a 


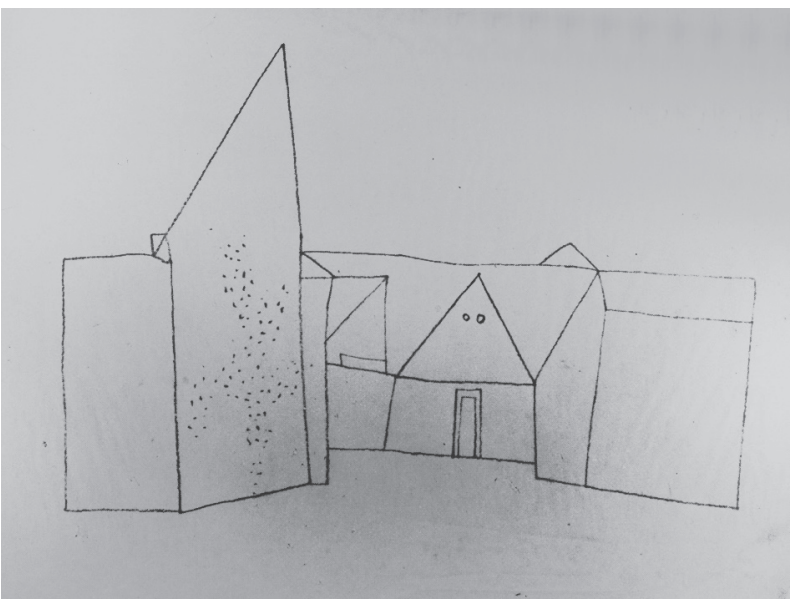

17. Vajda Lajos: Házak beszögelléssel, 1935.

Papír, ceruza, $31 \times 39$ cm. Magántulajdon (MS 1935/46)

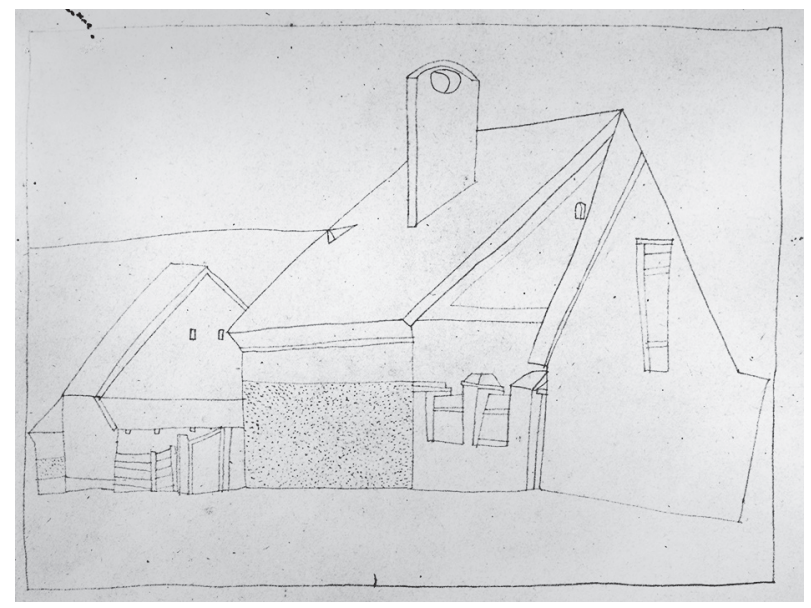

18. Vajda Lajos: Utcarészlet, 1936.

Papír, ceruza, $23 \times 31 \mathrm{~cm}$. Magántulajdon rajzon. A legkiemeltebb a jobb oldali ház tetőgerendáinak találkozásánál lévő. Azon a ponton helyezkedik el, ahol a ténylegesen ábrázolt épület és a fogalmi gondolkodást, a térmélységet jelölő keret találkozik. A kereszt mindkettőn kívül helyezkedik el. Egy újabb teret, az e világon túlit, az isteni szférát jelöli.

A Házak beszögelléssel címü rajzon (17. kép) az épületegyüttes egy zárt egészet alkot. Az előző rajzzal ellentétben az épületek alsó részei nem egy egyenesen helyezkednek el. A vízszintes képszélekkel párhuzamos egyenest meglepő módon a tetőszerkezetek felső élei adják ki. Ezt a vonalat csak egy féloromzat töri meg, illetve a zárt épülettömb mögött feltűnő távoli épület teteje. Az épületegyüttes a kép felső felében egy egyenessel határolt, amelyet kisebb építészeti elemek bontanak szakaszokra. Ez a formai megoldás emlékeztet Rashid al-Din képére. Ott a távolban megjelenő városfal zárja ugyanígy a képet. Vajda rajzán is értelmezhetjük ezt az egyenest a távolság érzékeltetéseként annak ellenére, hogy valójában az épületek tetejét ábrázolja. A részekből álló egyenes önálló szakaszai tehát a tetőket, azaz az épületek magasságát jelölik, ha azonban egységében, egy egész vonalként tekintünk rá, akkor horizontnak, azaz távolság, távlat megjelölésének érzékeljük. Ezzel a szerkezeti elemmel Vajda egyszerre két, egymással kilencven fokot bezáró irányban jeleníti meg a teret.

A horizontvonal hiányzik az Utcarészlet (18. kép) című grafikáján is. Annak ellenére, hogy a kép bal oldalán több vízszintes is feltünik, mégsem beszélhetünk a klasszikusnak számító elő-, közép- és háttértagolásról. A kép jobb oldalán megjelenő hiány, az ennek következtében létrejövő formatalálkozások, a pozitív és negatív formák felcserélhetôsége, a térértelmezés kettősségének lehetősége felülírja a megszokott térértelmezési rendszert. Tekintetünk egyszerre vezethet a távolba, a bal oldali egyre kisebb házak felé és a közvetlen közelbe, a jobb oldali be nem fejezett, tehát általunk nyitottnak, azaz végtelen nagynak érzékelt tér felé. A rajzot keretező négyszög lehet, hogy kompozíciós elem, de elképzelhető, hogy csak a kép határait jelöli. Nem kötődik szervesen a képi struktúrához. A fent bemutatott múvekhez hasonlóan a tudatosan befejezetlen struktúrák, a formai hiányok, a pozitív és negatív felületek játéka több Vajda-grafikán is megfigyelhetők (pl. Ház kerítéssel 1935, Szentendrei utca 1937).

\section{Az egyiptomi és a perzsa múvészet együttes hatása}

A Pettyegetett fưrészmintás ház (19. kép) címü grafikán az eddig vizsgált jellemzők összetett formában jelennek meg. Forma- és arányrendszere alapján a mú két rétegből épül fel. A fómotívum a papír aljához illesztett nagyobb méretü, részletmegoldásokban gazdag fürészmintás ház. A ház szerkezetét frontálisan látjuk, a befoglaló formát hangsúlyozza a dupla kontúr. A mü második rétegét a redukált geometriai elemek jelentik, amelyek nem ábrázolják, hanem csak formarészletekben utalnak a ház fogalmára. Az alakzatok elhelyezése alaposan átgondolt: az eresz függőleges vonala a jobb oldalra elhelyezett hegyesszögü háromszög és a fömotívum metszetéből kialakult felülettel ritmizál. A transzparencia, a ház fogalmi megjelenítése az egyiptomi múvészettel áll kapcsolatban. A pozitív és negatív formakapcsolatok és a főmotívum sík felületét áttörő ablak - amelynek vonalrendszere az épület belsejében lévő térre is utal - a perzsa miniatúrákkal hozható összefüggésbe. 


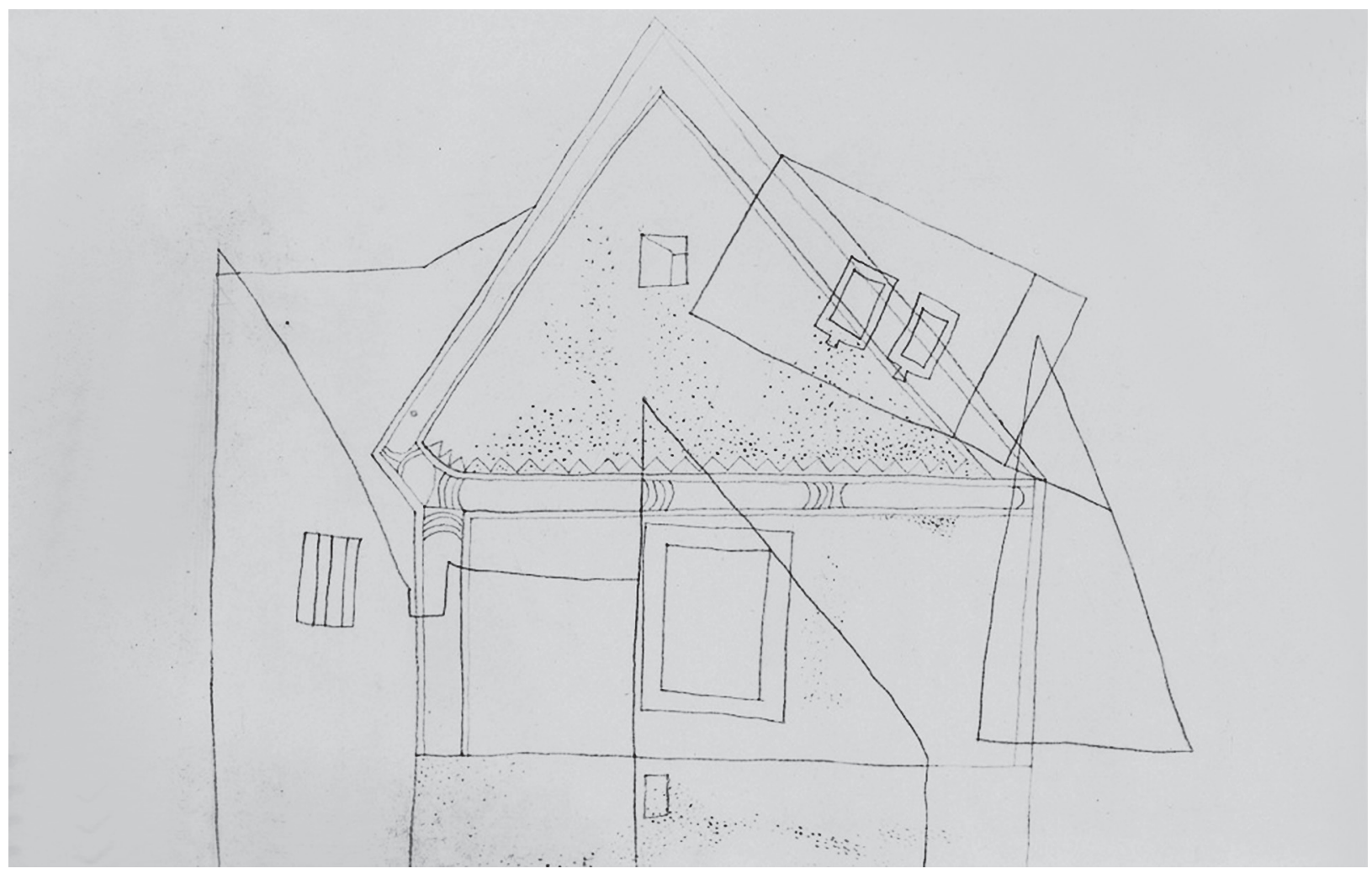

19. Vajda Lajos: Pettyegetett fürészmintás ház, 1935. Papír, ceruza, 30×46,6 cm. Magántulajdon (MS 1935/11)

A térfelfogásban az ember és környezetének viszonya tükröződik, amely koronként, kultúránként eltérően alakul. Vajda földrajzilag és korszakonként követte végig a tér ábrázolási lehetőségeit, az európai civilizációk mellett az antik és a távol-keleti kultúrákat is kutatta. Az eltérő kulturális szempontokat szem előtt tartva nemcsak mint jelenséget vizsgálta a különböző térábrázolási megoldásokat, hanem azoknak a magyarázatát is kereste. Így Vajda müvei e megértési folyamat dokumentumai. Tehát nem utal konkrétan az egyiptomi múvészetre, hanem abból indul ki, hogy a tér észlelésének többféle módja egyszerre lehet érvényes. A különböző gondolati rétegek között nem hierarchizál. Kísérleti városképként is fel lehet fogni ezeket az alkotásokat. Vajda Szentendre zegzugos utcáit, meredek, szük sikátorait járta, rajzolta, és ezekkel párhuzamosan olvasta a korszakot meghatározó térelméleti írásokat.

Nem térábrázolási szempontból, hanem a munkamódszer hasonlósága miatt megemlítendő a német orientalista Friedrich Sarre 1904-ben megjelent publikációja - a kicsi Pepita füzetben szerepel -, amely Rembrandt indiai-iszlám miniatúrák alapján készített rajzait tárgyalja. ${ }^{24} \mathrm{~A}$ tanulmány szerint
Rembrandt bibliai témájú képeinek előtanulmányaként készíthette ezeket a rajzokat. A miniatúrák másolásával és a keleti tárgyak gyưjtésével az lehetett a célja, hogy azokon keresztül valós képet kapjon a keleti életről, amelyet a bibliai témájú képeken hűen akart visszaadni. A művek összehasonlításánál Sarre kiemeli, hogy a Rembrandt müvészetét meghatározó fény-árnyék-viszonyok, melyek a miniatúrákon biztosan nem jelentek meg, ezeken a rajzokon is hangsúlyosak. Vajda Rembrandthoz hasonlóan az összegyüjtött forrásokban az általa fontosnak tartott problémák megoldási lehetőségeit kereste, de azt saját formanyelvéhez alakította.

Vajda olvasmányai alapján szerzett szellemi és vizuális élményei nagyon sokrétüek. A látszólag egyszerünek tünő vonalrajzok hátterében számos önálló gondolati egység húzódik. A művek nagyon eltérő kulturális gyökerekkel rendelkeznek, ennek következtében a - sajátos vonalhasználat miatt látszólag egységesnek tünő - rajzok vagy rajzcsoportok egymástól nagyon különböznek. Vajda esetében az azonos kulturális hatásnak egy-egy gondolata, illetve ábrázolási eszköztára több rajzon végigkövethető, ennek alapján a rajzok csoportosíthatóak. 


\section{JEGYZETEK}

1 Vajda megmaradt füzeteit jelen tanulmány írója dolgozta fel doktori disszertációjában, erről bővebben 1 . Radák Judit: Vajda Lajos Pepita füzetei. Kézirat. Eötvös Loránd Tudományegyetem Bölcsészettudományi Kar, Müvészettörténet-tudományi Doktori Iskola, Budapest 2013.

2 Jakovits Vera - Kozák Gyula: Vajda Lajos levelei feleségéhez, Vajda Júliához 1935-1941. Budapest 1996.

3 Mándy Stefánia: Vajda Lajos. Budapest 1983, 46-47.

4 Az olvasmánylistával kapcsolatban megemlítendő, hogy Vajda olvasottsága a Pepita füzetek alapján csak hipotézis, hiszen azok ismeretét csak néhány esetben bizonyítják egyéb írott források.

5 Adolf Hildebrand: A forma problémája a képzőmüvészetben. Ford.: Wilde János. Budapest (1893) 1910².

6 A korszak meghatározó térelméletei: Alois Riegl: Die spätrömische Kunst-Industrie. Wien 1901; Ernst Tross: Das Raumproblem in der bildenden Kunst: kritische Untersuchungen zur Fiedler-Hildebrandischen Lehre. München 1914; Heinrich Wölfflin: Kunstgeschichtliche Grundbegriffe: Das Problem der Stilentwickelung in der neueren Kunst. München 1915; Hans Berstl: Das Raumproblem in der altchristlichen Malerei. Bonn, Leipzig 1920; El Liszickij: K. und Pangeometrie. In: Europa Almanach, Potsdam 1925. 103-113. A Pepita füzetekben Riegl kivételével mindegyik mü szerepel.

7 Erről bővebben 1. Radák Judit: Vajda Lajos szentendrei városképei az antik egyiptomi térfogalom értelmezései alapján. In: Tanulmányok. Filozófiatudományi Doktori Iskola, Múvészettörténet-tudományi Doktori Iskola, Asteriskos 4. Főszerk. Bárdosi Vilmos. Budapest 2013, 301-310.

8 Heinrich Schäfer: Von ägyptischer Kunst besonders der Zeichenkunst. Leipzig 1919.

9 Vajda 1937. május 2-án írt levele. In: Jakovits-Kozák i. m. 20, 49-50.

10 Schäfer i. m. 45.

„1. A testek a képi ábrázolás számára áthatolhatatlanok. Ezért a közelebbiek eltakarják a távolabbiakat, amennyiben ezek a szemmel egy vonalban fekszenek. 2 . A távolabbi dolgok, magasságban és szélességben egyaránt, kisebbnek látszanak, mint az azonos nagyságú közelebbiek. 3. Egy vízszintes síkban vagy síkon a dolgok annál magasabban fekvőnek látszanak, minél távolabb vannak tőlünk, és szemünk [vonala] felett minél magasabban helyezkednek el." A magyar fordításért köszönet Szőke Annamáriának.
11 Polügnotosz (Kr. e. 5. sz.) nevéhez füződik a térbeliség érzékeltetése az antik görög vázákon.

12 Goethe, Johann Wolfgang: Polygnots Gemälde in der Lesche zu Delphi. In: Goethe's nachgelassene Werke. Hrsg. v. Eckermann und Riemer. Bb.43. Stuttgart, Tübingen, idézi Schäfer 1919. (mottó)

13 „Abból a magasságból, ahová újabb időkben a festészet lendült, újra visszatekinteni ösi kezdeteire, ezen művészet alapítóinak becses tulajdonságait magunkévá tenni és az ily múvek mestereit tisztelni, akik számára bizonyos ábrázolási eszközök - amelyek a mi tanulóink számára már megszokottak - ismeretlenek voltak, ehhez bizony eltökélt szándékra, nyugodt lemondásra és azon stílus magasabb értékének a belátására van szükség, amelyet joggal nevezhetünk lényeginek, mert inkább a tárgyak lényegével, mintsem azok látszatával törődik." A magyar fordításért köszönet Szőke Annamáriának.

14 Schäfer i. m. 78-79.

15 Uo. 79-80.

16 o. $104-107$

17 Vajda 1936. június 22-én írt levele. In: Jakovits-Kozák i. m. 30. Ezúton is köszönöm Kozák Gyulának, hogy a beszkennelt képeslapot elküldte nekem. A képeslap egyértelműen azonosítható a forrásban említettel, mert hátoldalán Vajda kézírásával ez olvasható (annak ellenére, hogy június helyett július szerepel): Júliámnak 1936 július Szentendre.

18 Catalogue des manuscrits à peintures, estampes, médailles, monnaies, objets d'art, livres et cartes (Kiállítási katalógus, Paris, Bibliothèque Nationale), Paris 1925.

19 Uo. 22. kép.

20 A miniatúra egy a Pepita füzetben megtalálható, másik könyvben is szerepel: Fredrik Robert Martin: The Miniature Painting and Painters of Persia, India, and Turkey from the 8th to the 18th Century. London 1912, 42. kép.

21 Szántó Ivánnal 2011 nyarán történt levelezés.

22 A miniatúra az alábbi könyvben szerepel: Philipp Walter Schulz: Die persisch-islamische Miniaturmalerei. Leipzig 1914, 42. kép.

23 A miniatúra a 20. jegyzetben hivatkozott könyvben szerepel: Martin i. m. 72. kép.

24 Friedrich Sarre: Rembrandts Zeichnungen nach indisch-islamischen Miniaturen. Jahrbuch der Königlich Preussischen Kunstsammlungen 25. 1904, 143-158.

\section{LAJOS VAJDA'S "SPATIAL DRAWINGS" SEEN THROUGH HIS INTERPRETATIONS OF EGYPTIAN AND PERSIAN IDEAS OF PERSPECTIVE}

The Hungarian painter Lajos Vajda left little in terms of documentation for posterity. His witten legacy is largely confined to three notebooks and a variety of scribbled notes that complement the letters saved by his wife.

Despite the scarcity of documentation, the three "chequered notebooks" (named after their chequered covers) provide a considerable insight into the scope of Vajda's reading especially when analysed in conjunction with the letters.
After initially attempting to "reconstruct" Vajda's intellectual background through his reading, I discovered an important gap in the academic research conducted into Vajda to date.

This related to the drawings of houses and streets in the small town of Szentendre that Vajda produced between 1935 and 1938 - contemporaneously with the writing of the Chequered Notebooks. These drawings have largely been seen as part of a larger project. However, my reading 
of these notes leads me to believe that they were selfstanding experiments in the depiction of space influenced by his concurrent reading and reflection on Egyptian and Persian ideas of the depiction of space.

Of especial interest is the role of Vajda's line drawings and the possibility of exchanging positive and negative forms. This problematic had already appeared in his earlier montage works but - despite the similarities in style - he now experimented with new solutions to the depiction of space.

The shapes do not mark overlapping layers of space but rather they enclose a special form through distortions projected onto the plane. Vajda did not use the usual systems of geometrical depiction (the Monge type depiction system, axonometric or one and two-point directional perspective) or depict the motifs from a single point of view, but drew the contours by following the detection and the direction of the gaze.
In summary, my research aimed at discovering the extent to which knowledge of the artist's reading material assists in the analysis of works created at the same time. In the comparison with the experiments in the depiction of space of that era, I was interested in how Vajda's experiments with space were different and what relationship they had with his reading material (Egyptian, Persian Art).

RADÁK Judit művészettörténész/art historian, Budapest, radakjuca@gmail.com

Kulcsszavak: Vajda Lajos, Pepita füzetek, szentendrei városképek, térábrázolás, egyiptomi kultúra, perzsa miniatúra / Keywords: Lajos Vajda, Chequered Notebook, Szentendre, depiction of space, Egyptian culture, Persian miniature 